\title{
MYB/NFIB Fusion Gene
}

National Cancer Institute

\section{Source}

National Cancer Institute. MYB/NFIB Fusion Gene. NCI Thesaurus. Code C129772.

A fusion gene that results from a translocation $t(6 ; 9)(q 22-23 ; p 23-24)$ that fuses the first

8,12 or 14 exons of the MYB gene upstream of exon 8 or 9 of the NFIB gene. This fusion is associated with adenoid cystic carcinomas. 